\title{
From Consensus to Conflict: The Experience of Pan- Malaysian Islamic Party (PAS) in Barisan Alternatif and Pakatan Rakyat
}

\author{
Mohd Izani Mohd Zain
}

To Link this Article: http://dx.doi.org/10.6007/IJARBSS/v11-i19/12086

DOI:10.6007/IJARBSS/v11-i19/12086

Received: 20 August 2021, Revised: 10 September 2021, Accepted: 27 September 2021

Published Online: 19 October 2021

In-Text Citation: (Zain, 2021)

To Cite this Article: Zain, M. I. M. (2021). From Consensus to Conflict: The Experience of Pan-Malaysian Islamic Party (PAS) in Barisan Alternatif and Pakatan Rakyat. International Journal of Academic Research in Business and Social Sciences, 11(19), 455-469.

Copyright: (c) 2021 The Author(s)

Published by Human Resource Management Academic Research Society (www.hrmars.com) This article is published under the Creative Commons Attribution (CC BY 4.0) license. Anyone may reproduce, distribute, translate and create derivative works of this article (for both commercial and non-commercial purposes), subject to full attribution to the original publication and authors. The full terms of this license may be seen at: http://creativecommons.org/licences/by/4.0/legalcode

Special Issue Title: Youth and Community Wellness, 2021, Pg. 455 - 469

Full Terms \& Conditions of access and use can be found at http://hrmars.com/index.php/pages/detail/publication-ethics 


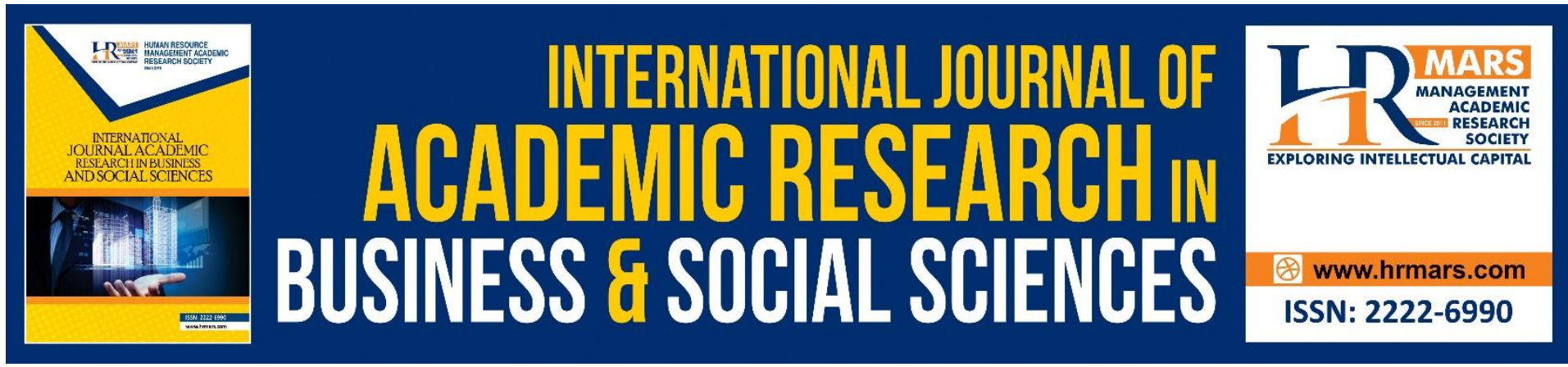

\title{
From Consensus to Conflict: The Experience of Pan-Malaysian Islamic Party (PAS) in Barisan Alternatif and Pakatan Rakyat
}

\author{
Mohd Izani Mohd Zain \\ ${ }^{1}$ Institute for Social Science Studies, Putra Infoport, Universiti Putra Malaysia, 43400 \\ Serdang, Selangor, Malaysia, ${ }^{2}$ Departrment of Nationhood and Civilization Studies, Faculty \\ of Human Ecology, Universiti Putra Malaysia (UPM) \\ Email:mohd_izani@upm.edu.my, eyerani@yahoo.com
}

\begin{abstract}
This article is an in depth discourse of how the Pan-Malaysian Islamic party (PAS) manages to zealously safeguard their fundamental political tenets while at the same time engaging in a new political coalition in an Alternative Front (BA) in 1999 and Pakatan Rakyat (PR) in 2008. These political leagues would assume a lasting feature as PAS explores a new terrain of cooperation that traverse more than an electoral pact. These collaborations which incorporated their shared beliefs and concerns for the sake of democracy, justice, freedom and good governance have unfolded up a new frontier of political leverage for PAS. This also suggests that the party should be less affectionate to its intrinsic party ideologues as it embraces the new coalition's common struggles. The qualitative approach of this study derived its data from extensive verbal interviews with seven prominent top key leaders in the PAS political leadership hierarchy. Several primary documents and minutes of numerous meetings are also scrutinously gleaned over for more informative details. The main striking discovery of this research illustrates that although PAS hopes that its collaboration with other parties would be an endurance one rather than winning an election. However, this never materialises as its efforts to reconcile between the differences of the party inherent principles and the coalition collective objectives ends in a stalemate situation. PAS has an underlying commitment that this cooperation would be able to expedite in fulfilling their Islamic agenda in establishing an Islamic Nation and the implementation of the Islamic hudud law which, on the other hand, do not augur well with the alliances common objectives and eventually imperilled their commutual understanding. This research is relevance in the sense that it looks at the survival of an Islamic party existence within the realm of a turbulent political coalition with other parties of different births. This study to a certain extent invariably interprets that the collaboration of PAS in the BA and PR, rhetorically speaking, is more at a stage of a coalition of convenience and of a short-lived in nature.
\end{abstract}

Keywords: Pan Malaysian Islamic Party, Political Coalition, Barisan Alternatif and Pakatan Rakyat 


\section{Introduction}

Historically speaking, PAS is a party unaccustomed to forming a political accord with other political parties. It used to be in partisanship with the National Party (Parti Negara) during the 1959 Malaysia General Election (Adam, 1998). It had formed an alliance with United Malay National Organisation (UMNO) in the National Front or Barisan Nasional (BN) and became part of the coalition federal government. It had also a political relationship with the Semangat 46 in Angkatan Perpaduan Ummah (APU) and formed a coalition state government in Kelantan. The intentions of its earlier alliance are antithetical with the latter alliances with BA and PR. The battle cry of the earlier collaboration is to preserve the vested interest of the Malay and Islam. On the other hand, the latter confederation is more of a general ideological clarion call on behalf of democracy, justice, freedom and good governance. Generally, it is not conscripted towards the establishment of an Islamic Nation or the implementation of the hudud law as expressed in the PAS party doctrine.

During PAS sojourn as a political affiliate in the bigger entities of BA and PR, its inherent party philosophy is subsumed under the Commutual Policy of the entities. PAS has to give priority in achieving the common goals rather than adhering to its own ideological objectives in an effort to win votes. This turn of event, has made PAS as a party that is more democratic, open and inclusive. Amazingly, PAS managed to secure a bigger wins during the general elections. In the Malaysia General Elections of 1999, PAS won 27 parliamentary seats and 98 sate seats. This is considered as a big leap forward in the history of the party, as it won the most seats among the opposition parties that even entitled its representative to be bestowed as the Opposition leader during the People Assembly or Dewan Rakyat sitting. In the 2008 General Elections it won 23 parliamentary seats and was able to wrest control of the state of Kelantan and the state of Kedah to be under its domain. In the 2013 General Elections, PAS managed to secure 21 parliamentary seats and maintained Kelantan.

On the other hand, PAS extraordinary political success has a pricy price tag. It rouses the political confidence of its grassroots members to demand that the time is ripe for PAS to accelerate the reification of its fundamental political ideals into reality, namely, the establishment of an Islamic Nation and the implementation of the hudud law. This is in direct contradiction with PAS's commutual stand with other parties which eventually led to the breakup of the coalition. Incidentally, the main cause of the failure of PAS's political cooperation during the Barisan Alternatif was the issue of Islamic state formation while the implementation of hudud laws during Pakatan Rakyat.

Several studies, among them such as Noor (2014); Hamid \& Razali (2020) show that PAS is actually still tied to the party's struggle such as establishing an Islamic state although at the same time, seeks to introduce a more tolerant and inclusive approach in political coalition. The party is also accused of experiencing an identity crisis when it still adheres to the party's struggle despite agreeing to support a common policy and remain in political coalition. PAS's political coalition in BA and PR associated with the post-islamic phenomenon also manifested with a new focus on issues and public interest and no longer the basis of the party's struggle (Long, 2017). However, this focus does not last long when PAS losing Malay votes in the elections and therefore, getting strong pressure from members to return to the party's core business. Because of that, PAS has always failed to defend its political coalition. It makes PAS a very complex political party.

Nonetheless, the findings of the study presented do not use a perspective within the party that could reflect that what really happened. Thus, this article seeks to fill this gap with the 
in-depth interviews, involving some PAS key leaders who have never done so. In evaluating how PAS strikes equilibrium between rendering the needs of the common goals and fulfilling their own fundamental political tenets, we need to understand this scenario from the viewpoints of several PAS key party leaders.

\section{Methodology}

This article uses in-depth interview methods to obtain data aimed at gaining a clear understanding of the consensus and conflict faced by PAS in political coalition, namely Barisan Alternatif and Pakatan Rakyat. Informants were chosen based on predetermined characteristics. Informants are the main leaders of PAS who are directly involved in exploring political coalition in Barisan Alternatif and Pakatan Rakyat. They have the authority to provide an important views regarding to PAS's experience in political coalition. Their selection is also very important to examine the important challenges and issues faced by PAS in political coalition. In addition, the views of some of them have never been explored and referenced in previous studies. The list of informants can be found in Table 1.

Table 1: List of informants

\begin{tabular}{lll}
\hline No. & Name & Brief info on informants \\
\hline 1. Dato' Husam Musa & Interviewed on 24 April 2014 in Salor, \\
& Kelantan. Husam Musa is a former PAS Vice \\
& President. Now he joins the Parti Amanah \\
& Nasional (PAN). \\
& Interviewed on 17 June 2014 in Kuala \\
& Lumpur. He was experienced in political \\
2. Dato' Mustafa Ali & cooperation and once held a cabinet post \\
& when PAS joined the government in 1974. \\
& Mustafa is a former PAS Secretary.
\end{tabular}

3. Dato' Ir. Iskandar Abdul Samad

4. Dato' Dr. Nik Muhammad Zawawi Nik Salleh

5. Dato' Dr. Mujahid Yusuf Rawa
Interviewed on 28 October 2015 in Ampang. $\mathrm{He}$ is one of the main leaders in the Pakatan Rakyat government in Selangor. Iskandar is currently the PAS Vice President.

Interviewed on 28 June 2016 in Kuala Lumpur. Nik Muhammad is currently the PAS Dewan Ulamak Chief and Member Parliament of Pasir Puteh.

Interviewed on 24 February 2014 in Parit Buntar. He is one of the pioneers of PAS cooperation with non-Muslims. Mujahid is currently the Parit Buntar Member of Parliament. Now he joins the Parti Amanah Nasional (PAN). 
6. Tuan Haji Nasharuddin Mat Isa

7. Hu Pang Chow

8. Dr. Mohd Zuhdi Marzuki
Interviewed on 21 April 2015 in Bandar Sri Putra. He dealt extensively in the cooperation of PAS and UMNO and the establishment of a unity government. Nasharuddin is a former PAS Deputy President

Interviewed on 17 March 2014 in Bangsar. He once got the confidence to contest the general election on a PAS ticket in the Ayer Hitam parliament. Hu Pang Chow is a former PAS Assembly Associate Supporters Chairman (DHPP).

Interviewed on 18 December 2014. Mohd Zuhdi is a former PAS Research Center, Director of Operation. He is currently the Political Secretary to Minister of Environment and Water.

The verbal information received was supplemented with primary sources texts such as the minutes from the Central Working Committee Meeting, the Central Working Committee Daily Meeting, a series of key note addresses from the President Policy Speech, during the Annual General Assembly (Muktamar) of the party, Presidential Speech during the Alternative Front and People Front Conventions, the Election manifestos, common policies of People Front and its bulletins. This research also went through the Party Media organ, Harakah and the mainstream media such as Berita Harian and Utusan Malaysia. The rarely known tabloid Eksklusif which was part of the alternative media since the inception of the reformative movement in 1999 was also inspected.

The Establishment of PAS Political Coalition in the Alternative Front or Barisan Alternatif (BA) and the People Front or Pakatan Rakyat (PR)

The Alternative Front or Barisan Alternatif (BA) was officially launched on the $3^{\text {rd }}$ of August 1999 ("Gerak dilancar Tumbang BN,"1999). Pas for the first time had to accomodate in a new cooperation with a motley of political parties of diverse genealogies. There was the Democratic Action Party (DAP) whose idealogical stands were at odds with PAS. National Justice Party or Parti Keadilan Nasional or PKR (KeAdilan) was a new party. Malaysia People Party or Parti Rakyat Malaysia (PRM) was a new reinvented party. Soon after the sacking of Anuar Ibrahim and the revival of the people reformation protest movement, the four parties decided to join hand for a common purpose agenda to advocate for the resurgence in actualising the idealistic concept of justice, freedom, democracy and good governance. In the beginning it was more of an electoral pact of the opposition coalition to depose the ruling coalition of National Front through exercising the voting rights of the people in a democratic setting of a general election ("Ingin Islam Perintah Malaysia," 1999).

The coalition of opposition parties appeared formidable when they agreed upon a commutual agreement on the 3rd of October 1999. Among the various sterling raison d'etre or rationale of their struggles they put forward to the Malaysian people were to promote and maintain the sanctity of an independent Malaysia; to create constitutionally a social democratic society; to design an economic system that provides equal rights to all Malaysian 
so that all the people would have an equal opportunity and receiving an equal income commensurating with their skills and abilities.

BA also contrived an electoral arrangment so that they would not be in the opposing position of a three-cornered fight during an election. In facing BN it would be a one to one contest As a result in the 1999 Malaysian General Election, there was a straight battle in 152 parliamentary seats and 367 state seats between BA and BN. PAS competed in 63 constituents (the most), followed by (KeADILan) in 59 constituents and DAP in 47 constituents while PRM in only 4 constituencies. PAS won big during that election, more than 4 times more seats in comparison to their performance in the previous 1995 general election. Pas secured 27 Parliamentary seats, DAP 10 seats, KeAdilan 5 seats while PRM did not get any seat. In the state constituencies PAS won 98 seats, gained control of the states of Kelantan and Terengganu, whereas DAP won 11 seats and KeADILAN 4 seats. PAS failed to maintain political cooperation in the BA because they did not agree with DAP on the issue of Islamic state formation. This will be discussed in the next discussion.

Nevertheless, seven years after the departure of DAP from the Alternative Front on $23^{\text {rd }}$ September 2001, a new front, the Pakatan Rakyat or People Front (PR) (The term of "Pakatan Rakyat" was suggested by PAS President in 2008) was officially launched on the $1^{\text {st }}$ of April 2008, 23 days after the 12th General Election. This was regarded as the second phase of the opposition coalition effort in consolidating and maintaining their alliance power based on a combined interest of key matters and public concerns while at the same time undertook a reciprocal concession understanding particularly in an election time. PAS, PKR and DAP were the key partners in this People Front alliance. The apex objective of the alliance this time around was more focus on a united stand of broad homogenous issues and interest, rather than highlighting the differences of each individual party idealogy.

The three parties have vouched on a Commutual Policy in seeking a meaninful cooperation in promoting democracy. Unwittingly, the Malaysian electorate for the first time in history was presented with a unprecedented huge alternative force in the coming election (Abdul Hadi, 2009). The Commutual Policy had four components, namely, Reestablishing a Truly Transparent Democracy, Generating a Higher Level of Economic Performance, Steadfast and Just, Social Justice and Human Development, Federal and State Relationship and Foreign Affair Relationship. PAS supported the PR alliance Commutual Policy. According to the PAS President Dato' Seri Abdul Hadi Awang, this Commutual Policy was the reflection of the people's hopes and aspirations as manifested in the federal constitution (Abdul Hadi, public speech, November 29, 2009). Besides the Commutual Policy, all participating parties in the People Alliace agreed unanmiously to uphold the basic status quo. They agreed to accept and protect Islam as the federal religion and the special position of the Malays and the bumiputera, to defend the role and the responsibility of the Constitutional Monarchy, to intensify the usage of the Malay Language as elucidated in the Article 152 of the Federal Constitution, to expand the use of the Malay Language as the regional lingua franca and to bolster the usage of the mother tongues of all races.

Astonishingly, during the 2008 Malaysian General Election, however, each individual party PAS, PKR and DAP put forward a separate party manifesto. Nevertheless, they were singularly united in wanting reform and revitalising democracy in Malaysia. PAS proclaimed a manifesto as, "Towards a Welfare Nation", on the other hand PKR manifesto was broadcast as, " A New Hope for Malaysia", while DAP exclaimed, "Let's Change (Jom Ubah)". It seems momentarily, Pas manifesto, did not mention the formulation of an Islamic Nation but more working towards realising the formation of a Welfare Nation. Apparently, PAS was 
determined to be the saviour of the people's welfare and national interest through an efficient and enlightened management of the economy and equitable development that is user-friendly to man and the environment. Like Barisan Alternatif, PAS failed to maintain political cooperation in Pakatan Rakyat due to their suggestions on the implementation of hudud laws. This also will be discussed in the next discussion.

\section{PAS and the Polemic of Commutual Policy in a Political Coalition}

Since PAS inception into the political coalition of the Alternative Front, PAS contention was that the opposition pact should give undisputed credence to issues of common interest rather than brooded over their differences. PAS President Dato' Fadzil Mohd Noor, also believed that the close opposition block camaraderie under the flag bearers of justice and humanity is a durable feature of the opposition against any attempt to dislodge it (Noor, 1999). PAS was able to see eye to eye with the DAP on the ground that they had common foes and issues that could be addressed politically. In the words of Lim Kit Siang, DAP stalwart, the basis of the cooperation of PAS and DAP was not to establish an Islamic Nation but rather to advocate the causes of their collective synonymous issues and public concerns (Siang, 2001).

The installation of an Islamic state and the attainment of the hudud law were never part of the political concord between the parties of the Alternative Front. These concepts were clearly absent in their Commutual Manifesto launched by the Alternative Front in confronting the $10^{\text {th }}$ Malaysian General Election. Their main focus was not in propagating the political dogma of each party but more in figuring how to handle the challenges of development for a just and transparent economic system, a social system that alleviates the plight of the poor and embarking towards a more open economy ("Manifesto Membela Rakyat," 1999). PAS stratagem, as reasserted by the former Pas Vice President Mustafa Ali, was that the coalition should not fuss over their parties differences in their joint homogenous stance. He elaborated,

\footnotetext{
"We formulate the manifesto together. At that time we did not give emphasis on topics of differences, but more on discussing about development matters."
}

In this context of political cooperation in the People Alliance, PAS affirmation towards the consensual policy rather than get distracted with its party agenda is the critical delicate bond of the alliance political unity. By converging in on the common issue and public interests the alliance was able to widen its appeal and voter support towards the opposition in general and to PAS in particular. This winning formula that the alliance was looking for that could be translated into the desired change that it was aiming for (Khalid, 2016).

Inadvertently, PAS tolerance approach in raising popular issues and mutual concerns rather than confining its struggle to its own agenda enable it to get access in promoting Islam more openly and inclusively. According to (Mujahid, 2012), by adopting such approach PAS had undergone a transformation into the third curve, a new phase that saw the evolution of the party becoming more mature as a national party rather than a localized party. What he meant by a national party was not a party that fought for the parochial national interest but rather a party that was able to comprehend and be supportive across the board of national issues acceptable to most Malaysians.

The question is to what extent can PAS withstand its commitment to give priority to the common issues and public interest as contained in their Commutual Policy understanding 
as compared to the demands to promote the primary tenets of PAS party struggle? Will PAS be more comfortable in promoting the original tenets of its struggle or feels shackled by the political manoeuvring in the alliance with regard to promoting Islam? This question is relevant as there is a wind of change in its pledge to the concept of Commutual Policy vis-a-vis in attaining the party jihad conviction.

The insistence by opposition alliance to give more credence and pre-eminence to the commutual policy has to certain extent hampered PAS desire to expound its philosophy at the same time. PAS concluded that it was pertinence for it to be more flexible in juggling their political commitment between complying with the objectives of the consensus policy and working towards their own party agenda. We can observe a paradigm shift in policies through the key note addresses by its political leaders during the PAS General Assembly (Muktamar) in the year 1999 and 2007 in the earlier stage of their political alliance as compared to the keynote addresses on polices during the PAS General Assembly (Muktamar) in 2008, 2014 and 2015 in the latter part of their political alliance when PAS was in political turmoil with other partner parties. During the $1999,45^{\text {th }}$ PAS General Assembly (Muktamar) the then PAS President articulated in his speech the concept of "Together we Uphold Justice" (Noor, 1999) and the key note address on policy in the $53^{\text {rd }}$ PAS General Assembly of 2007 he further expanded the idea to "Save Democracy and Uphold Justice," Generally speaking, in its earlier fellowship association PAS expressed more the desire in sustaining the common issues and public concerns about justice and humanity as the premier rallying call and to downplay their original party struggle.

Apparently, PAS mingling with the other parties reached a crossroad, where PAS wished for a new direction. The president key note address during the PAS $46^{\text {th }}$ Annual General Assembly (Muktamar) of 2000 extolled "PAS as Leader of Unity", and the president key note policy speech in the $60^{\text {th }}$ PAS AGA(M) of 2014 reminded the party to "Keep on be Consistent (Beristiqomah)" and PAS president speech in the 61 $1^{\text {st }}$ PAS AGA(M) of 2015 urged members to " (Beristiqomah) Be Consistent Until Victory". There appeared to be a reversal change of policy as the emphasis now was for party members to be consistent to the fundamental struggle of the party. Consistency or Istiqomah was the party new solidarity call. It was a aide-memoire or reminder for party members to be firmed on policy, practices and real struggle from Allah as Islam is a perfect everlasting religion consistent in its principles and flexible enough to be prescribed throughout the ages a scripted in the PAS constitution. The theme of consistency was successively recited gloriously over the two PAS AGAM in 2014 and 2015 for PAS to be consistent in terms of the party policy and undertaking and be firmed and unyielding when it comes to principles in the midst of the political wrangling with other parties.

Consequently, party leaders were regularly advised not to breach the boundary of cooperation of tahaluf in dealing with other parties so as "to safeguard the principles and inherent tenets of the party, be absolutely loyal to the party so not to abandon them in their enthusiaism to seek political gain". Political partisanship did not mean one should dissipate the prime mission of the party into the other form of struggle or system just for the sake of winning.

PAS resourcefulness in coordinating the equilibrium outcome between adopting the political objectives of the alliance that prioritise winning an election and to that of defending the mainspring struggles of the party was immensely successful but beginning to stir some restlessness during PAS $59^{\text {th }} A G A(M)$ on $15^{\text {th }}$ August 2008. This came about after 5 months of the $12^{\text {th }}$ Malaysia General Election of $8^{\text {th }}$ March 2008 when the opposition block won an 
unprecedented monumental victory in the election. It secured 82 parliamentary seats and captured the governments of over 5 states such as Kelantan, Kedah, Perak, Selangor and Penang. However this rises the contention whether after achieving a victory during an election means that the PAS can also be assured in realising its original goals? A victory during this election as the opposition block should not make PAS complacent in continuing their infinite mission for Islam as their inspirations and aspired orientation. More evidently, in 2010 PAS remodelled its approach in this political cooperation by putting forward a working paper entitled, "Tahaluf Siyasi (Political Alliance): Guidelines from an Islamic Perspective". This reinforces PAS intrinsic philosophical framework less it deviates from its primary purpose. Six guidelines are listed in forging political cooperation with other parties so that the party will not stray away from the righteous original path of the party struggle.

Consequently, PAS is aware that it should be able to juxtapose equally between the alliance aspirations for a triumph at the ballot boxes and honouring the party intrinsic beliefs. PAS as a bona fide functional Islamic party has to operate within the domains of the Islamic governance (sahsiah), missionary works (dakwah) and educating the masses (tarbiah). It is unavoidable that there would be a stiff showdown between the desire for power and the faithful adherence to principles (Keane, 1993). It makes PAS struggle more complex (Noor, 2016). This ceaseless internecine collision of ideas between the aims of getting the people approval as in winning in an election and the dreams to implement the primary principles of the party is synonymous as imploring for a synergy between the "voice" and the "syariah" (Burhanuddin, 2012). In this context the voice refers to the support and inspirations of the people while the syariah refers to the party principal resolution in establishing an Islamic Nation and the implementation of the hudud law.

\section{The Quest for Supremacy of Islam and Islamic Nation}

Although PAS seeks an equilibrium political posture in the alliance, its prime party objective is toward uplifting the supremacy of Islam as outlined in the principles of Tahaluf Siyasi (Political Alliance). In this regard, Nik Mohd Zawawi said that the primary political tenets of the party should remain intact, no withstanding PAS position in the alliance, where in reality it never abandons its true party mission for an Islamic victory. Mujahid Yusuf Rawa shared a similar view,

No party has dropped its basic party ideology. This is in our cooperative agreement. DAP cannot questions PAS Islamic ideologue. Neither do we question DAP slogan of, "Malaysian Malaysia or Democratic" or PKR who proposes a liberal approach for example. We respect their beliefs.

Subsequently, PAS should never be overzealous in wanting to win at the expense of sacrificing their fundamental party principles. Winning an election is not simply an electorate victory at the ballot boxes but a victory that could fulfill the PAS party constitution, Nik Mohd Zawawi said;

To struggle for a nation where the community and administrator that practise Islamic values and laws towards acceptance by Allah", PAS does not want to be seen in its political cooperation as simply to gain power and ignoring the fundamental tenets of its struggle.

Mohd Marzuki impassionedly stated that the most important element in an election victory was not the victory itself but to ensure that messages of the party struggle reach the masses. The messages are to promote and influence the people about PAS sacred pursuits about the sanctity and perfection of Islam, Islamic Nation concept and Islamic laws. He 
believed that the true victory for PAS is in achieving the party objectives, rather than winning in an election. Mohd Zuhdi stated;

Sometimes, it appears that PAS is not winning (we have won Kelantan) but in reality we are beginning to be accepted by most people. In the government too they are beginning to talk about the laws of Allah. We have got Islamic Nation concept in the Islamic Studies or Tasawwur Islam curriculum. So the people are already beginning to accept Islam, although PAS has not won.

PAS stance that places emphasis more on an Islamic victory rather than winning in an election was severely criticised by some individuals, including PAS former political leaders who had joined the Amanah party. One of them, Khalid Samad, said that by disputing the importance of an election success was more in making PAS as just another Non-Governmental Organisation (NGO). PAS should contemplate deeply at the benefits and liabilities implications of its actions (Khalid, 2016b). Such stance would discourage member from working hard to win in an election and ultimately would make PAS a weak party.

PAS wards off disapproval remarks about its conviction by still insisting that winning an election through a political alliance must go hand in hand with the resurgence perpetuation of its party Islamic charter. So it is mandatory that the election victory is a victory for Islam, which is the mainstay of the party ideals. PAS was against any effort to make it as a tool just to win an election. Dato' Seri Abdul Hadi maintained that it was an undisputed fact that the coalition election victory during the $12^{\text {th }}$ Malaysian General Election of 2008 was made possible due to the overwhelming efforts of its extensive party machinery and the hard work of its numerous party members not only for its party but for other parties as well.

The pinnacle objectives of PAS's constitution are to establish an Islamic Nation and the implementation of the hudud laws. These twin objectives are inherent parts of the party struggle. They were always a part of PAS dreams since joining the BA coalition, which unfortunately were not codified in the united commutual policy. The deputy PAS president of the time, Dato' Seri Abdul Hadi considered that PAS had two main stratagems in becoming part of the BA coalition. Firstly, it would associate itself with an Islamic group, such as People Justice Party or Parti Keadilan Rakyat (KeADILan) who was responsive to the idea of an Islamic Nation. Although the party was a multi-racial party, it was dominated by Malay Muslim members who were sympathetic towards Islam and also agreeable to an Islamic scholar image (Hafiz \& Redzuan, 2013). Abdul Hadi believed the acceptance of an Islamic Nation by KeADILAN was vitally important as this was the prerequisite condition on why PAS wanted to be in the political coalition "Ingin Islam Perintah Malaysia" in 1999.

Secondly, the other stratagem was the extraordinary ties with DAP which was only confined to mutual matters of common interest such as upholding justice and not related to the promotion of an Islamic Nation. PAS firm conviction in advocating this policy of an Islamic Nation let to the withdrawal of DAP from the pact. PAS was not perturbed by this withdrawal, although it had lost an alliance partner. PAS still maintained that a political partnership should not be an obstacle in accomplishing its sacred constitutional objectives.

PAS and DAP friendship was not as rosy as before, when PAS was adamant that its membership in the poltitcal alliance with other parties did not mean that it would abandon its desire for the creation of an Islamic Nation in Malaysia. The formation of the Islamic Nation would entail the Islamic law would be introduced. However, non-Muslims were exempted from this Islamic law. PAS was willing to face the consequences of its action. As a result, DAP officially quit from the pact on 23th September 2001. PAS would not step backward just to indulge with DAP's dissent. The party creed has been the source of the party inspiration since 
time immemorial. The decisive view of PAS was that it would still uphold its principal struggle for an Islamic Nation, while working in a political collaboration with other parties, even if it meant DAP would not be in the group.

Lim Kit Siang clarified that DAP rejection in the establishement of an Islamic Nation did not mean the Party was anti-Islam. It was based on the contention that an Islamic Nation would deny the rights of the non-Muslims and the non Muslims were not ready to live under a theocratic state, based on religious edicts, like the Islamic Republic of Iran. On the other hand, PAS believed DAP leaders misunderstood the true objectives of PAS struggles relating to Islam. The explanation of DAP leaders, particularly about Islam was also not clear enough to the opposition pact (Zain, 2005).

\section{The Contestation of Hudud Law}

Other than the formation of an Islamic Nation, another contentious issue was the implementation of the hudud law which was not in the consensus agreement of the opposition pact. According to Mustafa Ali, PAS responsibility in wanting to implement the hudud law cut across political consideration. He also defended PAS rights to implement the hudud law. Although DAP disagreed about implementing the laws, it had not right to prevent the law from being implemented. He stated,

Hudud is not a political factor but it is a responsibility more momentous than politics. You (DAP) disagree it is all right. But you cannot prevent PAS from doing it. It is our right. That's why we accept the premise 'agree to disagree'. PAS could not reject the Hudud Laws. I have explained that to DAP. PAS reiterated that it was willing to lose in the election and lost backing from the DAP and the voters as a result of their determination to install the Hudud Laws. PAS had also no objection if DAP wanted to resign from the pact because of it. Mustafa vehemently stressed,

"If you want to be out, you can go. But we will never abandon not at all. If we lose, we lose."

However, he hoped DAP should not be hasty in its decision and would remain in the political alliance. The firm statement from Mustafa Ali, clearly indicated PAS unflinching commitment to the Hudud laws to extend it was prepared to suffer the consequences of losing the election, support from DAP and support from the electorate. Besides Mustafa, another faithful PAS leader, Husam Musa impassionly recapitulated the same arguments as Mustafa, stressing that as PAS is an Islamic party it is its responsibility to implement the hudud law. He added that DAP was not an Islamic Party and was not expected to support PAS ideology with regard to hudud law. Nevertheless, he hoped for DAP to be matured enough to accept the hudud law, as non-Muslims were exempted from the law.

It is timely and fittingly for PAS to be more transparent and firm in advocating the party ideals. It is imperative that PAS should not hide its intention to promote Islamic jurisprudence or Syariah, in order just simply to win votes. PAS should announce to the people in advance its goal to realise the hudud law before and not after being in power. Its Vice President Iskandar Abdul Samad, who was also PAS Selangor Commissioner, emphasised that PAS should demonstrate openly to the people its wish to institute the hudud law. He explained that it was only fair that the people should know Pas intention so that the people can decide to legitimise the law or not. 
What is more important PAS should not be seen as eluding the people, specifically non-Muslims by withholding its underlying true motive in instituting the hudud law only after attaining political power. In this respect, PAS Kelantan government putting forward a Syariah Criminal Penal Enactment (2) (1993) 2015 was in line with the primary aims of the party cannon. It was also in accordance with the Tahaluf Siyasi concept, which stipulated that PAS could not conceal its intention simply because it wanted political support. As PAS was becoming more open in its struggle, it no longer had to be secretive and to make concession with its prime ambition. This also proved PAS courageous decision to be more transparent in its crusade is more sacrosant than winning an election through a political alliance.

DAP was the party that vociferously opposed PAS freedom to legitimise its party agenda in the political alliance. PKR was also in agreement with DAP that hudud law was not part of the deal of their alliance. It stated that PAS should get the green light from Presidential Council before a Hudud agenda was added ("PKR Sokong DAP Tolak Hudud", 2015). The sharp rebuttals from the two alliance partners distinctively indicated that PAS agenda was not in the menu of the united Commutual Policy. On the contrary, to go along with this policy was reprehensive to PAS as it had never sacrifice or relinquished the party sacred constitution just to relish a victory in an election ("PAS Tidak Akan Gadai Prinsip," 2018). Each party has its own goals which are not part of the Commutual Policy. Mustafa said that PAS considered their political coalition was one of a loose confederation and did not at all touch on each individual party obligations and battle plans.

The altercation over the implementation of the Hudud law was not only bustling between the component parties of DAP and PKR against PAS but also became a heated stirring issue of contention among some PAS party members who eventually took the final decision to break away from the party and formed their own Amanah Party. They argued that PAS was not honest in undertaking its pledge to honour the mutual understanding among the coalition members (Dzulkefly, 2016). They added that PAS should not be in a hurry to implement the hudud law as they should be done in a strategic manner. PAS should wait for a time when the party was more appealing to the general public first. Once the public acknowledged PAS sincerity than they could be in resonance with the party struggles, explained Husam. PAS should first regularly engage on common matters close to the people's hearts. Husam took the example of the Prophet Muhammad Rasulullah (s.a.w.)'s approach when he began his preaching by stressing on matters of common concerns first before venturing on to other matters.

Pas should be realistic in realising its utopian ideal by gaining popular support first before taking in any steps as outlined in its Tahaluf Siyasi. This meant the struggle to legalise the hudud law should be approached with great trepidation. Husam was of the view that wresting political power should be the first requisite before putting into effect the hudud law. PAS in a democracy should be more systematic and ingenious in its initiatives and be able to differentiate of how to act before gaining power and after gaining power. Husam stated;

We have to be practical. If we have no seat, what can we do? What are we fighting for? It is not only hudud but also corruption. We have no seat, even corruption we cannot get rid of. Even to restructure a just economic system, we cannot do it without power and without seat. This step by step approach is more crucial as there may be some differences in what we do before gaining power and after gaining power.

He attested that the enactment of the hudud law could only be feasible if PAS clinced political power. It went without saying that on obtaining the people mandate, it could have 
the authority to legislate for the Hudud law. If PAS was tied down with debating on single moot point, such as the hudud law but neglected to reach a consensus opinion than this is a losing battle for PAS.

The non-Muslims leader in DHPP was not in favour in instituting the hudud law. Its chairman, Hu Pang Chaw asserted that actualising the hudud law was not the pre-eminence and pressing demands of the moment. He suggested that PAS should concentrate more in resolving on topics of fighting corrupting, on political stability and on development, rather than on hudud law. Hu Pang Chaw stated,

With regard to hudud, I disagree. I am not anti hudud but the timing is not correct. Before you can establish the hudud law you need a lot of explanation. Now is a raining season you want to sell ice. Raining season is cold, what reason you want to give? Now is an election time. What do you want to campaign about? You should talk about anti-corruption, development and political stability. Now you want to talk about hudud. People ask what hudud is. Why hudud? How do you want to explain? What is the right version? The problem with PAS is that now is not the right time. In a raining season, you want to sell ice, the timing is not correct.

Nevertheless, these objection about the implementation of the hudud law felt on dear ears on PAS. PAS was adamant they wanted to administer the hudud law as it was bound by the Islamic syariat dictums. In the $61^{\text {st }}$ PAS Annual General Assemly (Muktamar), PAS president chastised those who apposed the hudud law including party leaders, that the party was impetuous and in haste in wanting to establish the hudud law. He reminded them PAS had long odyssey struggle since 1950's to consecrate the law. After a period of 40 years, PAS finally managed to inaugurate hudud law for the first time in Kelantan state in 1993 as part of the Enactment of the Syariah Criminal Laws. PAS gave an ultimatum to DAP to support the hudud law or the opposition political alliance would end "DAP Tidak Faham Bahasa" in 2015.

As usual DAP outspokenly denounced PAS statement and protested that hudud law was not part of the unified commutual policy within the People Front (Pakatan Rakyat). DAP stalwart and adviser Lim Kit Siang pointed out PAS had renegaged on its assurance before the General Election of 2013, not to give unduly emphasis on the implementation of the hudud law hastily. This ceaseless war of words over the Hudud issue meant PAS Tahaluf Siyasi was a redundant proposition, as it could not be accomplished ("Hudud: DAP Beri Ingatan Kepada PAS,"2015). As the two components partners were at loggerheads over each other stances, the harmonius relationship between DAP and Dato' Seri Abdul Hadi Awang finally collapsed (“DAP Kekal dalam Pakatan Rakyat, Putus Hubungan dengan Hadi,"2015). But unexpectedly DAP and PAS still maintained a strange sort of relatioship in a political understanding. Only that the DAP was very sored with Dato' Seri Abdul Hadi Awang and to rub salt in the wounds or add insult to injury DAP openly endorsed the candidature of PAS Presidential post to PAS vice president Ahmad Awang instead of Dato' Seri Abdul Hadi Awang during PAS Leadership Election for the year 2015 to 2017, ("Saingan Kerusi Parlimen Pertembungan Dua Suara," 2015). This roused the anger of PAS who regarded it as a political interference in an internal matter.

A major event unfolded during PAS 61st Annual General Assembly (Muktamar) when PAS accepted the undebatable resolution of PAS's Religious Scholars Wing (Dewan Ulamak PAS) to annul the Tahaluf Siyasi (Political Cooperation) with DAP. Simultaneously, this also abrogated PAS tie-up with the People Front (PR) ("Batal Pakatan dengan DAP,"2015). On the other hand, PAS still maintained a working relationship with PKR (KeADILan). A massive watershed transition took place in the party, the Religious Scholars group (Kumpulan Ulamak) 
of the party took over the leadership of the party. Those group who lost during this party election resigned from the party and established a new party called National Thrusworthy Party or Parti Amanah Negara (Amanah) (Samad, 2016). The new party headed by the former PAS vice president Mohammad Sabu declared its determination to work together with DAP and PKR. They eventually assembled a new opposition pact the Hope Alliance or Pakatan Harapan ("Konflik Dasar Parti Bayangi Ikatan Pakatan Harapan,"2016).

\section{Conclusion}

Pas protracted unpredictable political coalition with other parties cut across just in winning an election but also to build up their mutual collective understanding. Their concerted views and concerns about society bring PAS and DAP together despite their ideological differences. Political notations and terminologies about democracy, justice, freedom, and good governance are what that binds them together in BA and PR. This is despite the fact that they hold dearly to their original parties struggles. Nevertheless their relationship is both tumultuous and challenging. Consequently, it is bound to happen that the interest of the alliances and the basic struggles of each party would collude and shook their political coalition.

This article has undoubtedly shown that PAS somewhat upheaval political adventure is still shackled between appeasing the demands of the joint commutual policy of the alliances and its perpetual desire to install an Islamic Nation and the hudud law. The loose political linkup of the alliances is not binding which has a loophole that PAS exploited to its advantage to institute its own individual party agenda while still tie-down down to the partnerships. It raises the shaky contention that PAS selflessly looks up to its own party but looks down on its teammate in the alliances. Does it also mean that PAS is more concern about syariah than listening to the voice of the people? PAS is not willing to sacrifice its own party perennial ambition but more willing to forego the support of the people and being kept out of the alliances.

PAS is still grappling on how to deftly equilibrate in managing sometimes conflicting twin roadmaps of the alliance to that of its party. This failure is due in part to the contradiction that exists of between remaining faithful to the party principles and going for broke in order to acquire the glory of power through an electorate victory assisted by the alliances. As a whole, this whole episode that we have discussed indicates that PAS political coalition is a matter of coalition of convenience and short-lived in nature.

\section{References}

Adam, R. (1998). Kemelut politik semenanjung Tanah Melayu. Universiti Malaya Press.

Awang, A. H. (2009). President Policy Speech in the People Front Convention.

Awang, A. H. (2015). President Policy Speech in PAS 61st Annual General Assembly (Muktamar).

Awang, A. H. (2015). President Policy Speech in PAS $62^{\text {nd }}$ Annual General Assembly (Muktamar).

Awang, A. H. (2015). PAS for ALL. President Policy Speech in PAS $58^{\text {th }}$ Annual General Assembly (Muktamar).

Awang, A. H. (2015). President Policy Speech in PAS 61 $1^{\text {st }}$ Annual General Assembly (Muktamar).

Batal pakatan dengan DAP. (2015). Berita Harian. pg. 6

DAP tidak faham bahasa. (2015). Utusan Malaysia. pg. 5 
Deliberating and Debating (Munaqasyah) the $58^{\text {th }}$ President Policy Speech," A Welfare Nation is the Thrust of Fellowship ", on $26^{\text {th }}$ January 2013 at the Islamiyah Education (Tarbiyah) Center at Pengkallan Chepa, Kelantan.

Gerak dilancar tumbang BN. (1999). Eksklusif, 1, 2.

Hamid, A. F. A., \& Razali, C. H. C. M. (2020). Islam and its racial dynamics in Malaysia's 14th general election. In Meredith L. Weiss \& Faisal S. Hazis (eds.), Towards a new Malaysia? The 2018 election and its aftermath (pp. 149-169). National University of Singapore Press.

Hansard. (2012). $12^{\text {th }}$ State Assembly, $5^{\text {th }}$ term sitting, $1^{\text {st }}$ Meeting.

Hudud: DAP beri ingatan kepada PAS. (2015). Utusan Malaysia. pg. 5

Ingin Islam perintah Malaysia. (1999). Eksklusif, 07, 19.

Istilah Pakatan Rakyat dicadangkan Presiden PAS. (2008). Harakah. bil 1367. pg. N3

Keane, J. (1993). Power sharing Islam?. Liberty for Muslim World Publications.

Konflik dasar parti bayangi ikatan Pakatan Harapan. (2016). Berita Harian. pg. 11

Long, A. S. (2017). Kebangkitan semula Islam hingga pasca Islamisme. Penerbit Universiti Kebangsaan Malaysia.

Manifesto membela rakyat. (1999). Eksklusif, 29, 4.

Muhtadi, B. (2012). Dilema PKS: Suara dan syariah. Jakarta: PT Gramedia.

Noor, F. M. (1999). President Policy Speech in $45^{\text {th }}$ PAS General Assembly (Muktamar).

Noor, F. A. (2014). The Malaysian Islamic Party PAS 1951-2013. Petaling Jaya: Strategic Information and Research Development Centre (SIRDC).

PAS Central Daily Committee Meeting Reminder. (2001).

PAS tidak akan gadai prinsip. (2008). Harakah, 1379, F3.

PKR sokong DAP tolak hudud. (2015). Utusan Malaysia. pg. 6

Rawa, M. Y. (2012). Rejuvenasi PAS: Idea realiti aplikasi ke arah aspirasi massa. Ilham Centre.

RoketKini. (2015). DAP kekal dalam Pakatan Rakyat, putus hubungan dengan Hadi. Roketkini. http://www.roketkini.com/2015/03/24/dap-kekal-dalam-pakatan-rakyat-putushubungan-dengan-hadi/

Saingan kerusi parlimen pertembungan dua suara. (2015). Berita Harian. pg. 8

Samad, M. H. A., \& Othman, M. R. (2013). Reformasi 1998 dan kesannya terhadap pilihan raya umum ke-10, 1999 di Malaysia. Jurnal Pusat Kajian Demokrasi dan Pilihan Raya Universiti Malaya (UMcedel), 2(1), 73-90.

Samad, K. (2016). Dari PAS ke Amanah. Ilham Books.

Siang, L. K. (2001). BA \& Islamic State. Democratic Action Party

Zain, M. I. M. (2005). Islam dan demokrasi: Cabaran politik muslim kontemporari di Malaysia. Penerbit Universiti Malaya. 